\title{
Effect of cadmium toxicity on Vertebrates
}

Mona S. Zaki ${ }^{1}$, Alaa Zakaria ${ }^{1}$, Ismael Abd El-Moneen Eissa ${ }^{2}$, Ahmed Ismael Noor Eldeen ${ }^{1}$

${ }^{1}$ Department of Hydrobiology, National Research center, Dokki, Giza, Egypt

${ }^{2}$ Department of Fish Diseases and Management, Faculty of Vet. Med., Suez Canal University, Ismailia, Egypt

\section{Type of article: Short report}

\author{
Abstract \\ This short article reviews the effect of the toxicity of the heavy metal, cadmium, which, as a contaminant of \\ freshwater, is a threat to human health and can cause itai-itai disease. \\ Keywords: cadmium toxicity, itai-itai disease, toxicity
}

A great deal concern over the last few decades has been directed at the contamination of freshwaters with many different pollutants. The concentrations of heavy metals in the aquatic environment have increased dramatically due to industrial, mining, agricultural, and domestic activities (1). Due to the toxicity of heavy metals and their propensity for accumulating, discharging them into rivers or any other aquatic environment can adversely affect the diversity of aquatic species and damage vital ecosystems (2). Aquatic organisms, such as fish and shellfish that live in the polluted water can accumulate toxic metals until the concentrations exceed their concentration in the water to a significant extent. The metals they take up from the polluted water are concentrated at different levels in the various organs of aquatic organisms. For example, research has shown that cadmium concentrations are much higher in the gills and viscera of aquatic organisms than in their other organs (3). Cadmium is an extremely toxic heavy metal that is used extensively in mining, metallurgical operations, electroplating industries, in manufacturing vinyl plastics, and in making electrical contacts as well as metallic and plastic pipes. High concentrations of metals can accumulate in the tissues of most aquatic organisms because their feeding and metabolic processes concentrate the metals in specific body parts. Some studies of this process ion fish have indicated that cadmium may have toxic effects that result in alterations of the physiological processes in the blood and tissue of fish (4). Thus, it is important to monitor the concentrations of heavy metals in aquatic environments. Currently, there is more awareness of the importance of studying parasites that affect fish. This is important because parasitic species pose a major obstacle to the production of fish, causing about $80 \%$ of the diseases that afflict warm water fish (6). The relationship of parasitism and pollution is complex, and it involves phenomena in which parasitism may decrease the host's susceptibility to toxic compounds, which, in turn, can lead to either an increase or a decrease in the prevalence of certain parasites. Pollutants may have effects on the intermediate or alternate hosts in the parasite's lifecycle, thereby affecting the stages of the parasite's activities. In Egypt, some fish farms depend on agricultural drainage water mixed with industrial pollutants and phosphate fertilizers, which are the main sources of Cd in the environment (7). This observation is especially of concern in the Kafr El-Sheikh Governorate. Both types of pollution are significant sources of the cadmium pollution that affects the prevalence of internal parasitic diseases in cultured fishes (8). The present study dealt with most prevalent parasitic infection in the cultured O. niloticus in relation to the cadmium concentration in water in Kafr El-Sheikh fish farms. In this work, the main clinical findings in naturally infested $O$. niloticus showed of the parasites aggregated on the surface of the water and at the inlet pipe that provided water to the pond. Upon examination, it was apparent that some of the fish were making abnormal movements and had abnormal shapes (scoliosis). The results of this investigation showed that cadmium mainly causes deformities of then fishes' backbones, which possibly could be attributed to muscle spasms. The deformities also appeared as scoliosis and compression of the vertebral column. Other effects that were noted included loss of

\section{Corresponding author:}

Professor Dr. Mona S. Zaki, Department of Hydrobiology, National Research center, Dokki, Giza, Egypt. E-mail: dr_mona_zaki@yahoo.co.uk

Received: December 06, 2015, Accepted: January 17, 2016, Published: February 2016

iThenticate screening: January 06, 2016, English editing: February 02, 2016, Quality control: February 05,2016

(C) 2016 The Authors. This is an open access article under the terms of the Creative Commons Attribution-NonCommercialNoDerivs License, which permits use and distribution in any medium, provided the original work is properly cited, the use is non-commercial and no modifications or adaptations are made. 
appetite and escape reflex. These may be nearly similar to that recorded in an earlier study (9). These results may be attributed to the respiratory, osmoregulatory, and circulatory impairments that resulted from long-term exposures to heavy metals. The internal organs of the affected fish appeared pale and anemic, and it was observed that the liver, spleen, and gallbladder were enlarged. Signs of emaciation were evident on the surface of abdomen, where slight bulging was observed. The intestinal wall had ulcers, and, in some cases, it protruded from the anus, where there also was large amount of catarrhal mucoid secretion (10). This was likely due to the presence of trematodes, nematodes, cestodes, and thorny-headed worms that were embedded between the villi of intestine. This caused local damage to the intestinal mucosa and possibly peritonitis. Proteolytic enzymes may have been discharged by the adult worms, resulting in the degradation of the intestinal tissues (11-13).

\section{References}

1) Abbas, H.H. Zaghloul K.H. and Mousa, M.A. Effect of some heavy metals pollutants on some biological and histopatholigical changes in the blue tilapia oreochromis aureus . Egypt. J. Agric. Res. 2002; 80(3): $1395-411$

2) Abbas, H.H. and Mahmoud, H. M. Haematological and biochemical changes in oreochromis aureus and Clariasgariepinus exposed to mixture of copper and lead salts. Egypt. Basic Appl. Physiol. 2004; 1(3): 89106.

3) Abd El-Hady, O.K. Comparative studies on some parasitic infection on fishes in fresh and Polluted water sources. PhD. Thesis Fac. Vet. Med., Cairo Univ. 1998

4) Abd El-Kader, M.A.; Tork, I.Y and Magda A.A. Heavy metals pollution in drinking water and methods of removals. Alex. J. Vet. Sci. 1993; A(1): 65-9.

5) Abd El-Nasser, M.; Afify, S. H. and El-Bakkah, S.S. Haematological and histopatholigical studies on cadmium chloride on the freshwater fish, Tilapia nilotica. Proc. 5 Sci. Cong. Fac. Vet. Med. Assiut Univ. 1992: 7-17.

6) Drastichoa, J. Svbodova, Z, Luskova V. Elechovska, O. C and Kala B. P. Effect of cadmiu on blood plasma biochemistry in Carp (Cyprinuscarpio L.) Bull. Envion. Contam. Toxicoll. 2004;72: 733-40. DOI: 10.1007/s00128-004-0306-3

7) Edward. Metals in Aquatic Toxicology. An introductionary text book 2 edition, an intersciene publication. John Wiley and Sons, New York, 1993: 351-416

8) El-Atabny A. I. Cadmium and lead residue in some food animals and fish tissue at Manzala, Dakahlia, Zag. Vet. J. 1995: 32-90.

9) El-Bag ori, H. M. Pathological studies on some environmental pollution on some freshwater fish in sharkia Governorate. M.V. Sc. Thesis, Fac. Vet. Med. Zag. Univ. 2001

10) El-Deep El. pathological studies on fish of some chemically polluted areas at Alexandria province. M. V. Sc. Thesis. Fac. Vet. Med. Alex. Univ. 1993

11) El-Nabawi A.; Heinzow B and Kruse, H. Arsenic, cadmium, copper, mercury and zinic in fish from Alexandria region, Egypt. Contam. Toxicol. 1987; 39:889-897.

12) El-naffar, . K. and Shahawy G. A. Studies on the metacercariae of the Nile fishes at El-Minia Province, Egypt. Assuit Vet. Med. J., 1986; 15 (30): 38-55.

13) El-Naggar, A. M. Soaad A. Mahmoud and Safaa I. Tayel. Bioaccumulation of some heavy metals and histopathological alternation in liver of oreochromis aureus in relation to water quality at different localities along the Rie Nile, Egypt World Journal of Fish and Marine Science, 2009; 1(2): 105-114. 